\title{
Russell Wallace Chesney MD—a fond farewell
}

\author{
Robert Wyatt ${ }^{1} \cdot$ Aaron Friedman $^{2}$
}

Received: 8 June 2015 /Revised: 8 June 2015 / Accepted: 9 June 2015 /Published online: 27 June 2015

(C) IPNA 2015

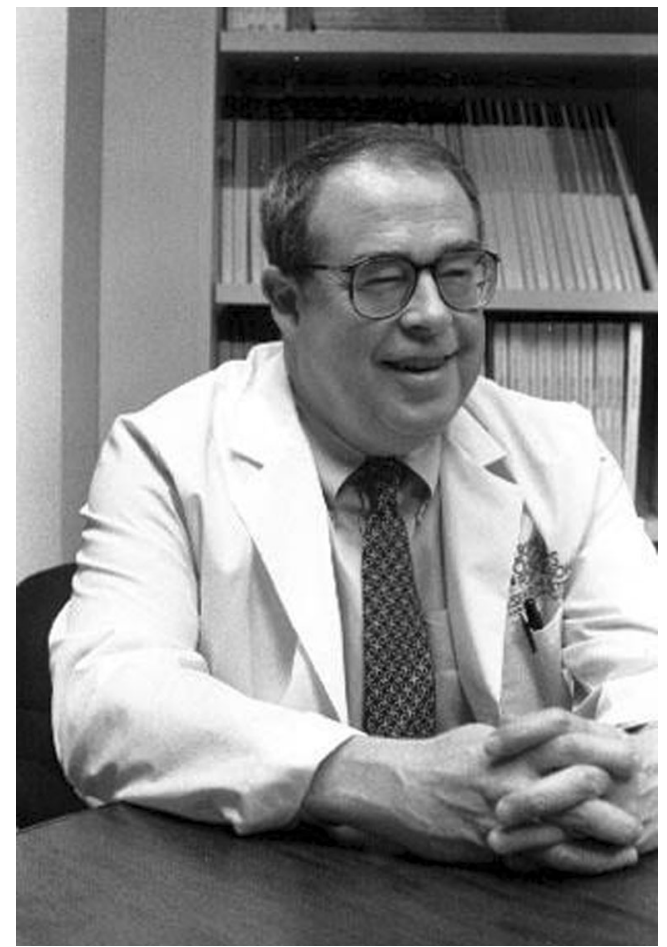

Aaron Friedman

alfried@umn.edu

Robert Wyatt

rwyatt@uthsc.edu

1 Department of Pediatrics, 301 WPT Le Bonheur Children's Hospital, 50 North Dunlap Street, 301 WPT, Memphis, TN 381032893, USA

2 Department of Pediatrics, 2450 Riverside Avenue, Minneapolis, MN 55454, USA
Russell Wallace Chesney MD died on April 2, 2015 in Memphis, Tennessee. He was 73 years old. Russell, or Russ, as many called him, was a major figure in pediatrics and pediatric nephrology for over 40 years. Born August 25, 1941 in east Tennessee, he was raised in Knoxville, Tennessee and completed his secondary education at St Andrew's School in Delaware. Russell received a Bachelor's degree from Harvard University and his MD degree from the University of Rochester. He began his medical research career at the University of Rochester, and while completing an internship and residency in pediatrics at the Johns Hopkins University he continued his research training at the National Institutes of Health in Baltimore, Maryland. From Johns Hopkins, he moved to McGill University in Montreal, Canada where he completed fellowships in pediatric nephrology and genetics. He trained with great mentors, such as Jordan Cohen, Bertram Sacktor, Barton Childs, Robert Cooke, Harold Harrison, Keith Drummond and Charles Scriver. In 1975, he joined the faculty of the University of Wisconsin, moving in 1985 to the University of California, Davis and then, in 1988, he became professor and Chair of Pediatrics at the University of Tennessee, Memphis, Tennessee and the Le Bonheur Children's Hospital. He served in those roles at the University of Tennessee and Le Bonheur Children's Hospital until his return to the faculty of the University of Tennessee in 2011.

Dr. Chesney contributed to the advancement of pediatrics and pediatric nephrology at the local, national and international level. He was an excellent clinician and superb academician. He published over 360 original manuscripts, nearly 180 book chapters and numerous letters to editors and abstracts. Throughout his career, he was a sought-after speaker around the globe. His areas of contribution included pediatrics, nephrology, education and workforce development. We would like to cite a few examples of the importance and breadth of his contributions. 
In the late 1970s, Dr. Chesney and his colleagues were among the first to publish the use of 1,25-dihydroxyvitamin $\mathrm{D}_{3}$ in children to treat the hypocalcemia, bone disease and growth failure due to renal osteodystrophy [1-3]. He continued to work in this area of interest and on rickets, in general, throughout his career. His basic science laboratory interest was in the developmental aspects of amino acid transport in the kidney. He used taurine as his "model" amino acid. He published extensively on this subject with his earliest taurine transport publication in 1979 [4] and his most recent publication in 2013 [5]. In 1980, Dr. Chesney was one of the first to describe the use of the antihypertensive captoril, an angiotensin-converting enzyme inhibitor, in children [6]. He teamed with his wife, Joan Chesney MD, to provide one of the earliest descriptions of toxic shock syndrome and its many clinical manifestations [7, 8]. In the fields of pediatrics and pediatric nephrology he published widely on hemolytic uremic syndrome [9], fluid and electrolyte management and workforce development in North America. Over the past decade, Dr. Chesney served as study chair of the National Institute of Diabetes and Digestive and Kidney Diseasessupported Randomized Intervention for Children with Vesicoureteral Reflux (RIVUR) trial [10]. He was brilliant but also continuously curious, always asking why and encouraging others to heighten their own curiosity and to act on their questions.

The above contributions would, for most, be a truly remarkable career. But Dr. Chesney took on, very successfully, leadership positions at local, national and international levels. He was the Chair of a large, diverse and successful Pediatrics Department and part of the leadership team at a very well respected Children's Hospital. He was a leader within: the American Society of Pediatric Nephrology (ASPN), serving as its President in 1985; the Midwest Society for Pediatric Research, serving as its President for the1986-1987 term; the Society for Pediatric Research (SPR), serving as its President in 1987; the American Pediatric Society (APS), serving as its President for the 2003-2004 term; the American Society of Pediatric Department Chairs as President (2001-2003). He served the American Academy of Pediatrics (AAP) as Chair of its Council on Pediatric Education (1989-1992) and as Chair of the Committee on Pediatric Research (1999-2004). He was a member of the Board of Directors of the American Board of Pediatrics and was its Chair for 2001. He was a leader of the International Pediatric Nephrology Association (IPNA) and editor of Pediatric Nephrology from 1997 to 2004. We all turned to Russell for his wisdom and insights, and he gave of himself, tirelessly, throughout his career.

Dr. Chesney was honored for his many contributions with the Meade Johnson Award (SPR) in 1985; The Joseph St
Geme Award given by the Federation of Pediatric Organization in the USA (2001); the Ira Greifer Award from IPNA in (2010); the Tennessee Chapter of the AAP Lifetime Achievement Award (2011) and highest award in pediatrics in the USA, the Howland Award from the APS in 2011.

Dr. Chesney's career was truly remarkable. He did so much and did it so well. We will remember him, not only for what he did, but also for his personal qualities. Everyone knew Russell-from his publications and lectures, from his ubiquitous presence at meetings and from his erudite questions. We know him for his prodigious knowledge and his exceptional memory. What is amazing is that we all felt Russell knew us. He was approachable, willing to listen and help and generous with his time and ideas. Many considered Russell a mentor and one who influenced them and helped them succeed. Joan Chesney said of Russell, "He does not take himself seriously but he takes what he does very seriously."

We are profoundly grateful for all Russell did for us, lucky to have had the opportunity to work with or learn from him and saddened to have lost him.

\section{References}

1. Chesney RW, Horowitz SD, Kream BE, Eisman JA, Hong R, DeLuca HF (1977) Failure of conventional doses of 1 alpha dihydroxy cholecalciferol to correct hypocalcemia in a girl with idiopathic hypoparathyroidism. N Engl J Med 297:1272-1275

2. Chesney RW (1978) 1,25 vitamin $D_{3}$ in reversal of secondary hyperparathyroidism in uremic osteodystrophy. N Engl J Med 298: 1424-1425

3. Chesney RW, Moorthy AV, Eisman JA, Jax DK, Mazess RB, DeLuca HF (1978) Increased growth after long term oral 1 alpha, 25 dihydroxyvitamin $\mathrm{D}_{3}$ in childhood renal osteodystrophy. $\mathrm{N}$ Engl J Med 298:238-242

4. Chesney RW, Jax DK (1979) Developmental aspects of renal beta amino acid transport I: ontogeny of taurine reabsorption and accumulation in rat renal cortex. Pediatr Res 13:854-860

5. Han X, Chesney RW (2013) Knockdown of TauT expression impairs human embryonic kidney 293 cell development. Adv Exp Med Biol 776:307-320

6. Friedman AL, Chesney RW, Ball D, Goodfriend T (1980) Effective use of captopril [angiotensin converting enzyme inhibitor] in severe childhood hypertension. J Pediatr 17:664-667

7. Chesney PJ, Chesney RW, Purdy WK, Davis JP (1980) Toxic shock syndrome in the United States. MMWR 29:229-236

8. Chesney JP, Davis JP, Purdy WK, Ward PJ, Chesney RW (1981) Clinical manifestation of toxic shock syndrome. JAMA 246:741748

9. Kaplan BS, Chesney R, Drummond KN (1975) Hemolytic uremic syndrome in families. N Engl J Med 292:1090-1093

10. RIVUR Trial Investigators, Hoberman A, Greenfield SP, Mattoo TK, Keren R, Mathews R, Pohl HG, Kropp BP, Skoog SJ, Nelson CP, Moxey-Mims M, Chesney RW, Carpenter MA (2014) Antimicrobial prophylaxis for children with vesicoureteral reflux. N Engl J Med 370:2367-2376 